\title{
Pengaruh Gaya Kepemimpinan Terhadap Motivasi Kerja Pegawai di Kantor Dinas Pekerjaan Umum Kabupaten Enrekang
}

\author{
Nur Wahid ${ }^{1}$; Sumarni Panting ${ }^{2}$; Nurbiah Tahir ${ }^{3}$ \\ ${ }^{1}$ Program Doktor Administrasi Publik, Sekolah Pascasarjana, Universitas \\ Hasanuddin Makassar, nurwahid139@gmail.com \\ ${ }^{2,3}$ Program Studi Ilmu Administrasi Negara, Fakultas Ilmu Sosial dan Ilmu \\ Politik, Universitas Muhammadiyah Makassar, suharni.panting@gmail.com, \\ nurbiahtahir@unismuh.ac.id
}

\begin{abstract}
Abstrak
Artikel ini bertujuan untuk mengetahui dan menganalisis pengaruh gaya kepemimpinan terhadap motivasi kerja pegawai di Kantor Dinas Pekerjaan Umum Kabupaten Enrekang. Jenis penelitian yang digunakan adalah penelitian deskriptif dengan menggunakan metode dan pendekatan kuantitatif yang menggambarkan gaya kepemimpinan terhadap motivasi kerja di Kantor Dinas Pekerjaan Umum Kabupaten Enrekang. Jumlah populasi dalam penelitian ini adalah seluruh pegawai di Kantor Dinas Pekerjaan Umum Kabupaten Enrekang yaitu sebanyak 40 orang. Penarikan sampel dalam penelitian menggunakan sampling jenuh. Berdasarkan hasil analisis data statisik tabel model summary, menjelaskan besarnya nilai korelasi atau hubungan $(\mathrm{R})$ sebesar 0,633 . Dari besar pengaruh variabel independen atau gaya kepemimpinan (X) terhadap variabel dependen motivasi kerja (Y) ditunjukkan oleh nilai $\mathrm{R}$ Square sebesar 0,401 artinya $40,1 \%$ besar pengaruh variabel independen atau gaya kepemimpinan terhadap variabel dependen motivasi kerja (Y) di Kantor Dinas Pekerjaan Umum Kabupaten Enrekang.
\end{abstract}

Kata kunci : Gaya Kepemimpinan, Motivasi Kerja, Pegawai

\begin{abstract}
This article purposed to determine and analyze the influence of leadership style on employee work motivation in the Public Works Office of Enrekang Regency. This study used descriptive research by using quantitative methods and approaches that described the leadership style of work motivation in the Public Works Office of Enrekang Regency. The population in this study were all employees in the the Public Works Office of Enrekang Regency as many as 40 people. This study used saturated sampling. Based on the results of the statistical analysis pf the summary model table, it explained the magnitude of the correlation or relationship (R) value of 0,663 . The influence style $(\mathrm{X})$ on the dependent variable of work motivation (Y) showed by the $\mathrm{R}$ Square value of 0,401 , it meant that $40,1 \%$ of the influence independent variable or leadership style on the dependent variable pf work motivation (Y) in the Public Works Office of Enrekang Regency.
\end{abstract}

Keywords : Leadership Style, Work Motivation, Workers 


\section{Pendahuluan}

Setiap perusahaan membutuhkan sumber daya manusia karena sumber daya yang yang dimiliki perusahan, terdapat sumber daya yang paling penting dalam menentukan keberhasilan perusahaan, yaitu sumber daya manusia yang merupakan salah satu faktor terpenting dalam perusahan karena manusia merupakan penggerak seluruh aktivitas dalam perusahaan.

Hal ini dapat dimengerti karena material, mesin, dan metode tidak dapat digerakkan tanpa adanya manusia. Mengelola sumber daya manusia yang ada disuatu perusahaan tentunya bukanlah hal yang mudah untuk dilakukan karena sumber daya manusia sangat sulit untuk diprediksi. Tiap-tiap individu memiliki keunikan tersendiri. Mereka memiliki kebutuhan, ambisi, sikap kehendak, tanggung jawab, serta potensi yang berbeda-beda. Untuk menyatukan banyak karakteristik yang berbeda-beda dalam mencapai suatu tujuan yang sama memerlukan peran seorang pemimpin. Seorang pemimpin akan memainkan peranan yang sangat domonan dikehidupan dalam perusahan. Peranan tersebut sama sekali tidak mengurangi, apalagi mengabaikan pentingnya peranan yang perlu dan harus dimainkan oleh para pegawai.

Melihat keterkaitan antara sumber daya manusia, organisasi kepemimpinan dan motivasi kerja menjadikan kepemimpinan begitu penting dalam suatu organisasi sehingga penetapan pimpinan atau jabatan pimpinan tinggi harus memiliki kriteria-kriteria khusus hal ini mendasari lahirnya undang-undang Republik indonesia nomor 5 tahun 2014 tentang Aparatur Sipil Negara di mana pada Bab V ketentuan umum pasal 19 ayat (3) berbunyi "untuk setiap jabatan pimpinan tinggi ditetapkan syarat kompetensi, kualitas, kepangkatan, pendidikan dan pelatihan, rekan jejak dan jabatan dan integrase, dan persyaratan lain yang dibutuhkan".

Dalam suatu perusahaan kepemimpinan, juga dipandang sebagai bentuk proses mempengaruhi dan perilaku untuk memenangkan hati, pikiran, dan tingkah laku. Namun kepemimpinan akan diakaitkan dengan proses perilaku orang lain dalam mencapai tujuan yang telah disepakati bersama (Setiawan \& Muhith, 2013). Kepemimpinan merupakan motor atau daya penggerak semua sumber-sumber dan 
alat-alat (resources) yang tersedia bagi suatu organisasi (Siagian, 2003). Dari dua defenisi di atas dapat disimpulkan bahwa kepemimpinan merupakan proses mempengaruhi seseorang dan sebagai penggerak dalam mencapai suatu tujuan.

Kepemimpinan merupak sifat-sifat, perilaku pribadi, yang yang pengaruh terhadap orang lain, pola-pola, interaksi, hubungan kerja sesame antarperan, kedudukan, dari satu jabatan administratif, atau juga presuasif, juga presepsi dari lain-lain tentang legitimasi pengaruh (Wahjosumidjo, 2005). Menurut George R. Terry dalam Miftah Thoha (2010) kepemimpinan merupakan suatu aktivitas untuk dapat mempengaruhi orang-orang supaya akan diarahkan mencapai tujuan organisasi. Gaya kepemimpinan merupakan norma perilaku yang digunakan oleh seseorang pada saat orang tersebut mencoba mempengaruhi perilaku orang lain atau bawahan.

Gaya kepemimpinan didefinisikan sebagai pola menyeleruh dari tindakan seorang pemimpin, baik yang tampak maupun yang tidak tampak oleh bawahannya (Rivai, 2008). Gaya kepemimpinan menekankan cara yang dilakukan oleh suatu pemimpin untuk mempengaruhi bawahan, orang lain ataupun suatu kelompok agar mereka mau bekerja sama dan bekerja secara produktif untuk mencapai tujuan organisasi (Hasibuan, 2007) (Golemon 2003).

Gaya kepemimpinan bukan bakat, oleh karena itu gaya kepemimpinan dipelajari dan dipraktekkan dalam penerapannya harus sesuai dengan situasi yang dihadapi (Yayat M Herujito, 2006). Gibson dalam (Setyowati 2013) mengemukakan motivasi konsep yang digunakan untuk menggambarkan dorongan-dorongan yang timbul pada seseorang, individu yang menggerakkan dan mengarahkan perilaku. motivasi merupakan tenaga pendorong atau penarik yang menyebabkan adanya tingkah laku kearah suatu tujuan tertentu (Muliyasa, 2003)

Keith Davis (2011) mengemukakan kepemimpinan dan motivasi dua hal yang berbeda, meski memiliki tautuan dalam konteks kerja dan interaksi antar manusia dan kepemimpinan adalah faktor manusiawi yang mengikat suatu kelompok bersama dan memberinnya motivasi menuju tujuan-tujuan tertentu baik dalam jangka pendek maupun jangka panjang. Namun pada kenyataanya dalam suatu organisasi atau perusahaan, motivasi kerja karyawan masih kurang 
didayagunakan secara optimal dalam rangka mencapai tujuan perusahaan.Karyawan yang mau dan mampu bekerja dengan upaya terbaiknya adalah faktor yang terpenting yang dimiliki suatu perusahaan. Untuk karyawan seperti itu, perusahaan harus memahami kebutuhan dan kemampuan karyawan.

Berdasarkan hasil observasi awal, peneliti melihat kurangnya motivasi yang diberikan pimpinan kepada bawahannya sehingga seringkali lalai dan kurang bersemangat dalam mengerjakan tugas yang diberikan kepada pimpinan. Karena beberapa pegawai juga mengatakan bahwa pimpinan tersebut menganut sistem sentralisasi wewenang yang dimana pimpinan ini dalam mengambil keputusan dan kebijaksanaan atau saran, ide dan pertimbangan hanya ditetapkan sendiri tanpa meminta pendapat dari para anggotanya dan masih ada kepemimpinan yang biasa digunakan pimpinan yaitu kepemimpinan partisipatif dan kepemimpinan delegatif.

Menurut Rivai (2008) motivasi adalah serangkaian sikapa dan nilai-nilai yang mempengaruhi untuk mencapai hasil yang spesifik sesuai dengan tujuan individu. Berelson Steiner yang dikutip oleh Kartono (2008) menyatakan bahwa motivasi adalah satu keadaan batiniah yang memeberikan energy kepada aktivitasaktivitas atan menggerakkannya, karena itu menjadi motivasi mengarahkan atau menyalurkan tingkah laku pada satu tujuan. Lebih jauh Hariandja (2002) mengemukakan bahwa motivasi adalah faktor-faktor yang mengarahkan dan mendorong perilaku atau keinginan seseorang untuk melakukan suatu kegiatan yang dinyatakan dalam bentuk usaha yang keras atau lemah. Selain itu ada juga yang memberikan pengertian motivasi sebagai konsep manajemen dalam kaitannya dengan kehidupan organisasi dan kepemimpinan, menyatakan bahwa motivasi ialah dorongan kerja yang timbul pada diri seseorang untuk berperilaku dalam mencapai tujuan yang telah ditentukan.

Berdasarkan penelitian terdahulu Reza (2010) membuktikan terdapat pengaruh antara motivasi dengan kerja pegawai. Pengujian membuktikan bahwa motivasi memiliki pengaruh positif terhadap kerja pegawai. Penelitian oleh Ilham Mawardi Siwesdi (2012) juga membuktikan bahwa terdapat pengaruh yang kuat dan positif antara gaya kepemimpinan dengan motivasi kerja. 
Keith Davis (2011) membahas bahwa kepemimpinan dan Motivasi merupakan dua hal yang berbeda, mesti memiliki tatuan dalam konteks kerja dan interaksi antar manusia, dankepemimpinan adalah faktor manusiawi yang mingikat satukelompok bersama dan memberinya motivasi menuju tujuan-tujuan tertentu, baik dalam jangka pendek maupun jangka panjang. Ini berarti antara kepemimpinan dan motivasi memiliki ikatan/ hubungan yang kuat.

Sumardianti (2016) telah membuktikan terdapat pengaruh antara gaya kepemimpinan dengan motivasi kerja pegawai. Dengan masalah-masalah yang terjadi diperusahaan menganggap penelitian ini sangat penting untuk mendorong karyawan agar dapat berprestasi dan dapat bekerja sesuai dengan apa yang diinginkan oleh perusahaan, maka setiap pegawai harus memiliki motivasi dan loyalitas yang tinggi terhadap perusahaan ditempat mereka bekerja sehingga dapat memberikan konstribusi positifnya dalam rangka pencapaian tujuan perusahaan, agar dapat penjadi acuan bagi setiap perusahaan.

Berdasarkan pada latar belakang dan penelitian terdahulu yang telah dipaparkan, maka pada artikel ini bertujuan untuk menganalisis dan memberi pemahaman mengenai pengaruh gaya kepemimpinan terhadap motivasi kerja karyawan dengan locus yang berbeda yaitu di Kabupaten Enrekang.

\section{Metode}

Penelitian ini menggunakan jenis penelitian kuantitatif dengan tipe penelitian deskriptif. Populasi dalam penelitan ini adalah pegawai di Kantor Dinas Pekerjaan Umum Kabupaten Enrekang yang berjumlah sebnayak 40 orang. Maka sampel penelitian ini berjumlah 40 orang. Teknik penentuan pengambilan sampel menggunakan teknik sampling jenuh.

Pengujian validitas cukup dengan membandingkan nilai rhitung dengan nilai rtabel Product Moment (lihat Lampiran).Jika nilai rhitung $\geq$ rtabel maka indikator atau pertanyaan kuesioner dikatakan valid, begitupula sebaliknya.Data juga dikatakan valid jika nilai sig. (2-tailed) data $<0.05$. dan akan melakukan uji reliabilitas dengan menggunakan bantuan software SPSS version 24.0. 
Pengujian realibilitas cukup dengan membandingkan ralpha atau angka cronbach alpha dengan nilai 0,7 .Jika ralpha atau angka cronbach alpha $\geq 0,7$ maka indikator atau pertanyaan kuesioner dikatakan reliabel,begitupula sebaliknya. Adapun teknik analisis data yang digunakan yaitu, teknik analisis statistik deskriptif yang akan digunakan dalam penelitian ini berupa tabel, perhitungan modus, median, mean (pengukuran tendensi sentral). Dalam perhitungan penyebaran data harus melalui perhitungan rata-rata serta standar deviasi, maupun perhitungan persentase $(\%)$. Penentuan persentase dari perolehan data hasil kuesioner dari masing-masing variabel menggunakan rumus perhitungan persentase:

$\%=\mathrm{n} / \mathrm{N} \times 100 \%$

Keterangan rumus:

$\mathrm{n} \quad=$ Skor yang diperoleh

$\mathrm{N}=$ Skor ideal

$\% \quad=$ Persentase

Adapun rumus persamaan regresi sederhana yang digunakan dalam penelitian ini adalah :

$\hat{Y}=a+b X$

Keterangan rumus:

Ý= variabel Motivasi Kerja Pegawai

$\mathrm{X}=$ variabel Gaya Kepemimpinan

$\mathrm{a}=$ konstanta

$\mathrm{b}=$ koefisien regresi

Analisis regresi dalam penelitian ini akan menggunakan bantuan software SPSS version 20.0. Hasil analisis regresi dapat digunakan pula untuk melakukan uji hipotesis yang telah diajukan sebelumnya. Dasar pengambilan keputusannya, adalah: (a) Jika nilai P value (sig) $\geq 0,05$, maka Ho diterima dan H1 ditolak (b) Jika nilai $\mathrm{P}$ value (sig) $\leq 0,05$ maka Ho ditolak dan $\mathrm{H} 1$ diterima.

\section{Hasil dan Pembahasan}

Penulis akan menyajikan data-data yang diperoleh selama penelitian yang telah dilakukan di Kantor Dinas Pekerjaan Umum Kabupaten Enrekang. Data ini 
diperoleh melalui kuesioner yang didistribusikan kepada 40 pegawai di Kantor Dinas Pekerjaan Umum. Kuesioner yang dibagikan terdiri dari dua variabel. Variabel $\mathrm{X}$ yaitu untuk mengetahui pengaruh gaya kepemimpinan dan variabel Y yaitu untuk mengetahui motivasi kerja pegawai yang diberikan di Kantor Dinas Pekerjaan Umum. Penyajian data meliputi data-data tentang identitas dan distribusi jawaban responden di Kantor Dinas Pekerjaan Umum terhadap pertanyaan ataupun pernyataan yang diajukan dan diuraikan dalam tabel frekuensi yaitu, deskriptif data identitas responden.

Dari hasil analisis dapat diketahui bahwa jenis kelamin untuk laki-laki mendominasi yaitu sebanyak 23 responden (57,5\%), sedangkan jenis kelamin perempuan 17 responden (42,5\%). Responden berdasarkan umur 25-32 tahun yaitu 10 orang (25\%), kelompok umur 35-40 tahun yaitu 17 orang (42,5\%), kelompok umur 41-50 tahun yaitu 7 orang (17,5\%), dan kelompok 52-56 tahun yaitu 6 orang (15\%). Dan juga diketahui responden berdasarkan lama bekerja 5-10 tahun yaitu 27 orang (76,5\%), kemudian 12-20 tahun yaitu 8 orang (20), sedangkan pegawai paling sedikit yaitu 25-29 tahun yaitu 5 orang(12,5\%). Berdasarkan pendidikan terakhir S1 sebanyak 33 orang (82,5\%), sedangkan magister (S2) lebih sedikit yaitu berjumlah 7 orang $(17,5 \%)$.

Setelah keseluruhan data yang diperoleh pada saat penelitian dari hasil kuesioner dikumpulkan, maka tahap selanjutnya yaitu melakukan analisis data tentang variabel X "Pengaruh Gaya Kepemimpinan" dan juga menjawab pertanyaan dari rimusan masalah pertama peneliti yaitu untuk mengetahui bagaimana gaya kepemimpinan di Kantor Dinas Pekerjaan Umum Kabupaten Enrekang. Adapun indikator gaya kepemimpinan yaitu sebagai berikut :

Kepemimpinan Otoriter. Jika kekuasaan atau wewenang, sebagian besar mutlak tetap berada pada pimpinan atau pimpinan itu menganut sistem sentralisasi wewenang. Terdiri atas lima deskriptor yaitu : pimpinan Bapak/Ibu menganggap organisasi sebagai milik pribadi, pimpinan Bapak/Ibu tidak mau menerima saran dari bawahannya, pimpinan Bapak/Ibu mengatur bawahan sesuai dengan keinginannya, pimpinan dalam tindakan menggunakn pendekatan yang menganut unsur paksan dan hukuman, dan pimpinan terlalu bergantung pada kekuasaan 
formalnya. Berdasarkan analisis maka penilaian rata-rata dari 40 responden yaitu $33 \%$ responden sangat setuju (SS), 57,5\% responden setuju (S), 8\% responden ragu-ragu (RR), $1,5 \%$ responden tidak setuju (TS) terhadap indikator kepemimpinan otoriter. Berdasarkan hasil penelitian tersebut menunjukkan bahwa indikator kepemimpinan otoriter berada pada tingkat penilaian sangat baik. Berdasarkan analisis penilaian rata-rata dari 40 responden yaitu $25 \%$ responden sangat setuju (SS), 63\% responden setuju (S), 11,5\% responden ragu-ragu (RR), dan $0,5 \%$ responden tidak setuju (TS).

Kepemimpinan Partisipatif. Apabila dalam kepemimpinannya dilakukan dengan cara presuasif, menciptakan kerjasama yang serasi, menumbuhkan loyalitas, partisipatif pada bawahan menunjukan bahwa memiliki penilaian sangat baik terhadap indikator kepemimpinan partisipatif yaitu sebesar $88 \%$ responden, penilaian tersebut diperoleh dari hasil analisis indikator kepemimpinan partisipatif sebesar $63 \%$ responden setuju dujumlah dengan $25 \%$ responden sangat setuju, namun dengan begitu masih ada beberapa responden yang memberikan penilaian tidak baik yaitu sebesar $12 \%$ responden diperoleh dari penilaian 11,5 ragu-ragu dijumlah $0,5 \%$ tidak setuju.

Kepemimpinan Delegatif. Seorang yang mendelegasikan wewenang kepada bawahan dengan lengkap. Dengan demikian bawahan dapat mengambil keputusan dan kebijaksanaan dengan bebas atau leluasa dalam melakukan pekerjaan. Jumlah dengan 92,5\% responden, penilaian tersebut diperoleh dari hasil analisis indikator kepemimpinan delgatif sebesar 56,5\% responden setuju dijumlah dengan 36\% sangat setuju. Namun dengan begitu masih ada beberapa responden yang memberikan penilaian tidak baik yaitu sebesar 7,5\% responden diperoleh dari penilaian sebesar 7,5\% responden ragu-ragu. Berdasarkan hasil analisis data dari ketiga indikator variabel X "Pengaruh Gaya Kepemimpinan" dapat disimpulkan pada tabel 4.8 penilaian di Kantor Dinas Pekerjaan Umum Kabupaten Enrekang mendapatkan hasil sebesar 78,4\% yang menunjukkan bahwa pelaksanaan responden pada variabel X "Pengaruh Gaya Kepemimpinan berada pada penilaian baik dari perolehan nilai sebesar 78,4\%. Dengan hasil yang diperoleh pada variabel $\mathrm{X}$ hal tersebut menggambarkan bahwa gaya kepemimpinan sudah berjalan sesuai 
dengan tujuan Kantor Dinas Pekerjaan Umum hal tersebut dibuktikan pada tanggapan responden terhadap kuesioner yang dibagikan dan pada saat peneliti berada dilapangan dan melihat langsung keadaan pegawai dalam menjalankan tugasnya. Pimpinan kantor bekerja sama dengan pegawai dalam pemberian tugas agar dapat berjalan dengan baik.

Motivasi kerja pegawai adalah segala segala sesuatu yang mendorong atau menggerakkan dan mengaktifkan orang lain atau diri sendiri guna mencapai tujuan yaitu memenuhi atau memuaskan kebutuhan. Hal tersebut dapat dilihat pengaruhnya dari hasil kuesioner peneliti pada Variabel Y "Motivasi Kerja” yaitu untuk mengukur sejauh mana peningkatan motivasi kerja pegawai di Kantor Dinas Pekerjaan Umum Kabupaten Enrekang. Adapun indikator motivasi kerja yaitu sebagai berikut :

Meningkatkan produktivitas pegawai dengan produktivitas yang tinggi, aktivitas yang dilakukan akan diselesaikan dengan baik, sehingga akan memberikan keuntungan pada perusahaan. Meningkatkan produktiivitas pegawai terdiri atas lima deskriptor. Berdasarkan data tabel 4.9, penilaian rata-rata dari 40 responden yaitu $37,5 \%$ responden yang sangat setuju, 60\% responden setuju (S), 2,5\% reponden ragu-ragu (RR). Indikator meningkatkan produktivitas pegawai di lingkungan Kantor Dinas Pekerjaan Umum Kabupaten Enrekang menunjukkan bahwa memiliki penilaian sangat baik yaitu sebesar 97,5\% responden, penilaian tersebut diperoleh dari hasil analisis indikator meningkatkan produktivitas pegawai sebesar $60 \%$ responden setuju dijumlah dengan $37,5 \%$ responden sangat setuju. Namun dengan begitu masih ada beberapa responden yang memberikan penilaian tidak baik sebesar 2,5\% responden yang diperoleh dari penilaian sebesar $2,5 \%$ responden ragu-ragu.

Meningkatkan kedisiplinan pegawai menjadi kunci terwujudnya tujuan perusahaan pegawai dan masyarakat. Dengan disiplin yang baik berarti pegawai sadar dan bersedian menggerakkan semua tugasnya. Meningkatkan kedisiplinan pegawai terdiri dari lima deskriptor. Berdasarkan tabel 4.10 penilaian rata-rata dari 40 responden yaitu responden yaitu 32,5\% responden yang memberikan penilaian sangat setuju (SS), 62\% responden yang memberikan penilaian setuju (S), 5,5\% 
responden yang memberikan penilaian ragu-ragu (RR), 0\% responden yang memberikan penilaian tidak setuju (TS), dan $0 \%$ responden yang memberikan penilaian sangat tidak setuju (STS) terhadap indikator meningkatkan kedisiplinan pegawai di Kantor Dinas pekerjaan Umum Kabupaten Enrekang. Untuk melihat indikator meningkatkan kedisiplinan pegawai untuk melihat motivasi kerja pegawai di lingkungan Kantor Dinas Pekerjaan Umum Kabupaten Enrekang menunjukkan bahwa penilaian sangat baik dengan hasil perhitungan sebesar 94,5\% responden, penilaian tersebut diperoleh dari hasil analisis indikator meningkatkan kedisiplinan pegawai sebesar $62 \%$ responden setuju dijumlah dengan $32,5 \%$ responden setuju. Namun dengan begitu masih ada beberapa responden yang memberikan penilaian yang tidak baik yaitu sebesar 5,5\% responden yang diperoleh dari sebesar 5,5\% responden ragu-ragu.

Meningkatkan moral pegawai merupakan kunci pendorong moral, kedisiplinan, dan prestasi kerja pegawai dalam mendukung terwujudnya peruahaan. Meningkatkan moral pegawai terdiri dari lima deskriptor. Berdasarkan tabel 4.11 dapat disimpulkan bahwa indikator meningkatkan moral pegawai penilaian ratarata dari 40 responden yaitu $35,5 \%$ responden yang memberikan penilaian sangat setuju (SS), 63\% responden yang memberikan penilaian setuju (S), 1,5\% responden yang memberikan penilaian ragu-ragu $(\mathrm{RR}), 0 \%$ responden yang memberikan penilaian tidak setuju (TS), dan $0 \%$ responden yang memberikan penilaian sangat tidak setuju (STS) terhadap indikator meningkatkan moral pegawai di Kantor Dinas Pekerjaan Umum Kabupaten Enrekang. Indikator meningkatkan moral pegawai untuk melihat peningkatan motvasi kerja pegawai di lingkungan Kantor Dinas Pekerjaan Umum menunjukkan bahwa memiliki penilaian sangat baik sebesar 98,5\% responden, penilaian tersebut diperoleh dari hasil analisis indikator meningkatkan moral pegawai sebesar $63 \%$ responden setuju dijumlah dengan $35,5 \%$ responden setuju. Namun dengan begitu masih ada beberapa responden yang memberikan penilaian yang tidak baik yaitu sebesar $1,5 \%$ responden yang diperoleh dari sebesar 1,5\% responden ragu-ragu. Berdasarkan perhitungan dari analisis data dari tiga indikator variabel Y "Motivasi Kerja Pegawai" dapat dismpulkan bahwa gaya kepemimpinan memberikan pengaruh yang sangat baik terhadap motivasi 
kerja pegawai. Hal ini membuktikan bahwa semakin baik motivasi pimpinan yang diberikan kepada pegawainya maka semakin baik pula hasil yang diperoleh dari motivasi kerja pegawai.

Pengaruh Gaya Kepemimpinan Terhadap Motivasi Kerja Pegawai di Kantor Dinas Pekerjaan Umum Kabupaten Enrekang dapat dilihat pada tabel di bawah ini :

Tabel 1. Model Summary

\begin{tabular}{|c|r|r|r|r|}
\hline Model & $\mathrm{R}$ & $\mathrm{R}$ Square & $\begin{array}{c}\text { Adjusted R } \\
\text { Square }\end{array}$ & $\begin{array}{c}\text { Std. Error of the } \\
\text { Estimate }\end{array}$ \\
\hline 1 &, $633^{\mathrm{a}}$ &, 401 &, 385 & 3,631 \\
\hline
\end{tabular}

a. Predictors: (Constant), Gaya_Kepemimpinan

Sumber: Olah data

Tabel 2. Anova

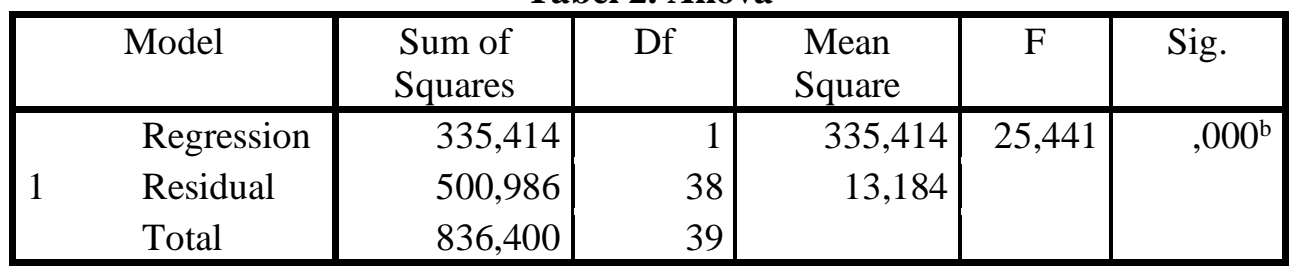

a. Dependent Variable: Motivasi_Kerja

b. Predictors: (Constant), Gaya_Kepemimpinan

Sumber: Olah data

Tabel 3. Coefficients ${ }^{\mathrm{a}}$

\begin{tabular}{|c|c|c|c|c|c|}
\hline \multirow[t]{2}{*}{ Model } & \multicolumn{2}{|c|}{$\begin{array}{l}\text { Unstandardized } \\
\text { Coefficients }\end{array}$} & $\begin{array}{l}\text { Standardized } \\
\text { Coefficients }\end{array}$ & \multirow[t]{2}{*}{$\mathrm{T}$} & \multirow[t]{2}{*}{ Sig. } \\
\hline & $\mathrm{B}$ & $\begin{array}{l}\text { Std. } \\
\text { Error }\end{array}$ & Beta & & \\
\hline$($ Constant $)$ & 26,442 & 7,626 & & 3,467 & 001 \\
\hline Gaya_Kepemimpinan & 607 & 120 & 633 & 5,044 & 000 \\
\hline
\end{tabular}

a. Dependent Variable: Motivasi_Kerja

Sumber: Olah data

Berdasarkan tabel di atas dapat disimpulkan bahwa pengaruh variabel gaya kepemimpinan (X) terhadap variabel motivasi kerja pegawai (Y) dapat ditentukan dengan menggunakan analisis regresi sederhana. Regresi sederhana dapat dilakukan untuk menganalisis pengaruh antara variabel independen yaitu gaya kepemimpinan (X) terhadap varibael dependen yaitu motivasi kerja pegawai (Y) di Kantor Dinas Pekerjaan Umum Kabupaten Enrekang. Pengambilan keputusan dalam uji regresi linear sederhana memicu pada dua hal yakni : 
1. Jika nilai signifikan lebih kecil $<0,05$ artinya variabel berpengaruh terhadap variabel, maka Ha diterima dan Ho ditolak.

2. Jika nilai signifikan lebih besar $>0,05$ artinya variabel $\mathrm{X}$ tidak berpengaruh terhadap variabel Y, maka Ha ditolak dan Ho diterima.

Berdasarkan hasil analisis data statistik tabel Anova digunakan untuk menentukan model persamaan regresi sederhana yang diketahui bahwa nilai Fhitung $=25,441$ dengan tingkat signifikan 0,000 lebih kecil dari $<0,05$ maka variabel gaya kepemimpinan $(\mathrm{X})$ berpengaruh terhadap variabel motivasi kerja (Y). Adapun rumus model persamaan regresi sederhana yang digunakan dalam menentukan besar pengaruh variabel $\mathrm{X}$ terhadap variabel $\mathrm{Y}$ dalam penelitian ini sebagai berikut :

$\mathrm{Y}=\mathrm{a}+\mathrm{bX}$

$Y=26,442+0,607(0)$

$\mathrm{Y}=26,442$

Berdasarkan persamaan regresi di atas maka dapat disimpulkan bahwa nilai kofisien regresi (b) nilainya sebesar 0,607 yang menyatakan bahwa jika gaya kepemimpinan (X) niainya 0 maka hasil motivasi kerja (Y) nilainya positif 26,442. Setiap penambahan $1 \%$ nilai gaya kepemimpinan maka nilai motivasi kerja semakin bertambah sebsar 0,607 koefisien regresi tersebut positif, sehingga dapat dikatakan berpengaruh antara variabel gaya kepemimpinan (X) terhadap variabel motivasi kerja (Y) dengan nilai sebesar 26,442. Apabila ditingkatkan nilai gaya kepemimpinan (X) maka motivasi kerja (Y) akan semakin meningkat berarti ada pengaruh antara gaya kepemimpinan terhadap motivasi kerja pegawai di Kantor Dinas Pekerjaan Umum Kabupaten Enrekang.

Berdasarkan hasil analisis data statistik tabel model summary menjelaskan besarnya nilai korelasi atau hubungan $(\mathrm{R})$ sebesar 0,633 dari output tersebut diperoleh dari koefisien determinasi ( $\mathrm{R}$ Square) 0,401 atau 40,1\% yang mengandung arti bahwa pengaruh gaya kepemimpinan $(\mathrm{X})$ terhadap motivasi kerja (Y) di Kantor Dinas Pekerjaan Umum Kabupaten Enrekang sebesar 40,1\% sedangkan sisanya 0,599 atau 59,9\% yang diperoleh dari $100 \%-59,9 \%=40,1 \%$ 
yang merupakan variabel yang diteliti sedangkan 59,9\% variabel lain yang tiak diteliti.

\section{Kesimpulan}

Berdasarkan hasil penelitian yang dilakukan tentang pengaruh gaya kepemimpinan terhadap motivasi kerja pegawai di Kantor Dinas Pekerjaan Umum Kabupaten Enrekang, maka dapat ditarik kesimpulan sebagai berikut :

Gaya kepemimpinan di Kantor Dinas Pekerjaan Umum sudah diterapkan dengan sangat baik, hal sesuai dengan jawaban responden dari kuesioner yang dibagikan peneliti serta hasil perhitungan pada tabel 4.8 yang menunjukkan bahwa gaya kepemimpinan yang dijalankan pimpinan di Kantor Dinas Pekerjaan Umum Kabupaten Enrekang berada dalam kategori sangat baik yaitu sebesar 78,4\% hasil yang diperoleh dari perhitungan rata-rata kuesioner peneliti.

Motivasi kerja pegawai yang dijalankan pegawai di Kantor Dinas Pekerjaan Umum sangat baik, hal sesuai dengan jawaban responden dari kuesioner yang dibagikan peneliti serta hasil perhitungn pada tabel 4.12 yang menunjukkan bahwa motivasi kerja pegawai yang diterima oleh pegawai di Kantor Dinas Pekerjaan Umum Kabupaten Enrekang berada dalam kategori sangat baik yaitu sebesar $85,5 \%$ hasil diperoleh dari perhitungan rata-rata kuesioner peneliti.

Berdasarkan hasil analisis statistic tabel 4.22 model summary, menjelaskan besarnya nilai korelasi atau hubungan (R) sebesar 0,663. Dari besar pengaruh variabel $\mathrm{X}$ "Gaya Kepemimpinan " terhadap variabel $\mathrm{Y}$ "Motvasi Kerja Pegawai" ditunjukkan oleh nilai R Square sebesar 0,401 artinya 40,1\% pengaruh variabel gaya kepemimpinan (X) terhadap variabel motivasi kerja pegawai (Y) di Kantor Dinas Pekerjaan Umum Kabupateb Enrekang. Berdasarkan hasil pengujian hipotesis yaitu dengan mengkonsultasikan nilai t hitung dengan nilai $\mathrm{r}$ tabel, dan melakukan uji t yang diketahui bahwa t hitung $>\mathrm{t}$ tabel $(26,442>1,683)$ atau signifikan (Sig) sebesar 0,0000 lebih kecil dari < 0,05 sehingga berarti Ha diterima dan H0 ditolak. Hal ini berarti gaya kepemimpinan berpengaruh terhadap motivasi kerja pegawai di Kantor Dinas Pekerjaan Umum Kabupaten Enrekang. 


\section{Referensi}

Golemon, D. (2003). Kepemimpinan yang Mendatangkan Hasil. Yogyakarta: Amara Books.

Hariandja M. T. E. (2002). Manajemen Sumber Daya Manusia. Jakarta: PT. Grasindo.

Hasibuan, H. (2007). Manajemen Sumber Daya Manusia. Jakarta: PT. Bumi Askara.

Kartono, K. (2008). Pemimpin dan Kepemimpinan. Jakarta: PT. Raja Grafindo Persada.

Keith, D. (2011). Perilaku Dalam Organisasi. Jakarta: Erlangga.

Muliyasa, A. (2003). Kurikulum Berbasis Kompetensi. Bandung: Remaja Rosda Karya.

Regina A. R. (2010). Pengaruh Gaya Kepemimpinan Motivasi Kerja Pegawai. Semarang: Universitas Diponegoro.

Rivai, R. (2008). Kepemimpinan dan Perilaku Organisasi. Edisi Kedua. Jakarta: PT. Raja Grafindo Persada.

Setyowati, S. (2013). Organisasi dan Kepemimpinan Moderen. Yogyakarta: Graha Ilmu.

Siagian, S.P. (2003). Filsafat Administrasi. Jakarta: PT Bumi Askara.

Sumardianti, S. (2016). Pengaruh Gaya Kepemimpinan terhadap Motivasi Kerja Pegawai paa Kantor PT. PLN (Persero). Makassar: Universitas Negeri Makassar.

Swesdi, I.M. (2012). Pengaruh Gaya Kepemimpinan terhadap Motivasi Kerja Pegawai. Bandung: Universitas Widiyatama.

Thoha, M. (2010). Kepemimpinan dan Manajemen. Jakarta: PT.Raja Grafindo Prasada.

Wahjosumidjo, W. (2005). Kepemimpinan Kepela Sekolah, Tinjauan Teori dan Permasalahannya. Jakarta: Raja Grafindo Prasada. 